\title{
Functionalization and Structural Characterization of a Novel Nacrite-LiCl Nanohybrid Material
}

\author{
Nouha Jaafar, Sonia Naamen, Hafsia Ben Rhaiem, Abdesslem Ben Haj Amara* \\ Laboratory of Physics of Lamellar Hybrid Materials and Nanomaterials, Department of Physics, Faculty of \\ Science of Bizerte, Zarzouna, Tunisia \\ Email: ${ }^{*}$ abdesslem.bamara@fsb.rnu.tn
}

Received 29 December 2014; accepted 27 January 2015; published 30 January 2015

Copyright $@ 2015$ by authors and Scientific Research Publishing Inc.

This work is licensed under the Creative Commons Attribution International License (CC BY). http://creativecommons.org/licenses/by/4.0/

(c) (i) Open Access

\section{Abstract}

The nacrite-LiCl hybrid composite material was prepared at room temperature by indirect intercalation of lithium chloride between the planar layers of nacrite, a clay mineral, using acetone as a solvent. The structural identification of the hybrid clay material was determined by means of X-ray diffraction (XRD), thermogravimetric analysis (TGA) and infrared spectroscopy (IR). The qualitative XRD analysis showed that the basal spacing value increased from $0.72 \mathrm{~nm}$ to $1.14 \mathrm{~nm}$ and revealed that the alkali halide intercalated successfully in the interlayer space of the nacrite framework. The quantitative XRD analysis allowed us to determine the optimum structural parameters related to the position and number of keyed ions and water molecules per half unit cell calculated along the $c^{*}$ axis and the goodness of fit parameter $\left(R_{p}\right)$. The thermal properties of the elaborated hybrid were in great accordance with the XRD study and confirm the intercalation of the hydrated salt in the interlamellar space of nacrite. Moreover, IR spectroscopy enabled the study of the interactions between the silicate "networks" and the alkali halide.

\section{Keywords}

Nacrite, Composite Material, X-Ray Diffraction, TG Analysis, Infrared Spectroscopy

\section{Introduction}

Kaolin $\left[\mathrm{Al}_{2} \mathrm{Si}_{2} \mathrm{O}_{5}(\mathrm{OH})_{4}\right]$ is an abundantly available and relevant clay resource, with enormous industrial applications in porcelain, pottery, ceramics [1], paper manufacturing, pharmaceutical and cosmetic industries [2] [3].

\footnotetext{
"Corresponding author.
} 
Although, kaolin has potential environmental applications in nuclear waste treatment and in adsorbance and removal of heavy metals via the zeolite synthesis, etc. [4] [5]. Most of the applications of kaolin refer to its low cost, easy availability, non-toxicity, bulk properties and its surface chemical properties [6].

The kaolin group is divided in three polytypes (i.e. nacrite, kaolinite, dickite) in addition to halloysite their hydrated analogue. Kaolin-type clay is a two-layer silicate mineral consisting of alternating layers of silica tetrahedron and aluminium hydroxide octahedron. The sheet thickness is around $0.72 \mathrm{~nm}$. The hydrogen bonding between the hydroxyl group of the octahedral sheet of one bilayer and the tetrahedral oxygen of the adjacent silica sheet of the next bilayer holds the two layers together [7]. With such a configuration and by adding very low organic and/or inorganic precursor content to the layered silicate, it is possible to tailor kaolin into various structures of hybrid clay nanocomposites [8] [9] while maintaining the structural features of the host clay material [10]-[12]. However, hybridization is eventually accompanied by substantial modifications of the kaolin surface of this silicate layer due to the expansion of the interlamellar space and complexation via hydrogen bonding [13] [14]. The resulting hybrid materials have attracted much interest from researchers, since they frequently show unexpected and remarkable improvements in the rheological, mechanical, thermal, optical and electrical properties compared to the unmodified silicate mineral. In the case of nacrite-polytype study, the intercalation of inorganic salts and dipolar organic molecules is well documented and numerous publications are available [15]-[18].

In this paper, a continuation of existing literature data is presented focusing eventually on the intercalation of $\mathrm{LiCl}$ alkali halide in the interlayer space of nacrite. Nacrite crystallized in the monoclinic lattice with a Cc space group [7], the 2M stacking mode of nacrite is well described using the following structural parameters: $a=$ $8.906 \AA, b=5.146 \AA, c=15.669 \AA, \beta=113.58^{\circ}$ with a basal distance equal to $\mathrm{d}_{002}=c \sin \beta / 2=7.18 \AA$ [19].

Indeed, three intercalation modes of alkali halides into the kaolin sub-group can be distinguished: Mode $A$ includes those species that are directly intercalated: Michaelian et al., [20] proposed three different techniques related to this mode: In the first technique, the components are thoroughly mixed in small test tubes by manual shaking for about $5 \mathrm{~min}$; in the second one, the mixtures are ground in a mechanical mortar grinder for $30 \mathrm{~min}$ in ambient atmosphere (air grinding); in the third technique, the mixtures are ground mechanically for 60 min but from time to time a few drops of water are added during the grinding process in order to keep the mixture moist (wet grinding). However, the intercalation reaction associated with the first two methods is much slower than the third one, and the increase of the grinding period results in the amorphization of kaolinite framework. Lapides et al., [21] proposed an additional treatment-method consisting of grinding clay-salt mixtures with a limited amount of water and then pressing them into disks. However, reactions between the kaolin mineral and the salt may occur during the preparation of the disk since complications may arise from further kaolinite/alkali halide interactions when pressing the components into disks [20]. Mode B includes those species which can enter the interlayer space by means of an "entraining agent" such as hydrazine or ammonium acetates [21]. Mode $\mathrm{C}$ includes those species which can only be intercalated into the interlayer space by the displacement of a previously-intercalated compound such as dimethylsufoxide "DMSO" [21].

In this study, Mode B has been adopted, firstly, due to the strong interlayer bonds governed by van der Waals' forces between the hydrogen atoms of the hydroxyls in the octahedral sheet and the oxygen atoms in the tetrahedral sheet [22] which prevent the direct incorporation of some substances into the nacrite interlamellar space. Secondly, this process ensures the fast intercalation of the alkali halide without destruction of the kaolinite framework complications of the kaolinite/alkali halide interactions compared to Mode A. Finally, the protocol of synthesis followed in Mode B is much easier in comparison to that in Mode C. For these reasons, potassium acetate "KAc" was the best precursor selected for the expansion of nacrite; KAc is widely used as a small and highly polar molecule for the synthesis of materials that cannot be directly intercalated [21] [23]. The resulting KAc complex is characterized by a basal distance equal to $1.4 \mathrm{~nm}$, it is then washed with water and air dried leading to a stable hydrate, which constituted the starting material for the next step of the synthesis of the new hybrid material [23]-[25].

The inorganic salt employed during the course of this work was imposed by the literature data [21] [26]. However, in the previous cases the intercalation of $\mathrm{Li}^{+}$ion failed. The research carried out by Garrett et al. [27] showed that direct intercalation of halloysite, according to Mode A, does not occur with lithium chloride $\left(\mathrm{d}_{001 \text { (halloysite-Licl) }}=7.5 \AA\right)$. Their results suggested that the effect of the ionic potential (charge/size) was related to the intercalation ability. Only low potential salts form intercalation complexes. The intercalation of lithium chloride into kaolinite following the same mode has failed due to the hygroscopic properties of the salt-clay mixture. Thus, this research has been the first to intercalate $\mathrm{LiCl}$ in the interlamellar space of nacrite. 


\section{Experimental}

\subsection{Materials}

Well-crystallized Tunisian nacrite from north-east Tunisia (Jbel Slata, Kef) was used in this work as the starting clay [23]. This layered mineral contributes a large particle size and a high chemical stability and has previously been described and characterized [15] [16] [19] [23]-[25].

The nacrite-KAc was obtained after 14 days of manipulation, where $51 \mathrm{~g}$ of potassium acetate (Normality = $26 \mathrm{~N}$ ) were added to $4 \mathrm{~g}$ of natural nacrite and mechanically shaken. The nacrite-KAc hybrid was then washed two times with water leading to a stable-homogeneous hydrate [25].

Experiments based on the use of water as a solvent leads to the incomplete intercalation of $\mathrm{Li}^{+}$cations. For this reason, different organic solvents (acetone, methanol, ethanol, glycerol and ethylene glycol) were tested until an intercalation of $0.82 \mathrm{~g}$ of $\mathrm{LiCl}$ was obtained in presence of $20 \mathrm{ml}$ of acetone at room temperature. Indeed, for $\mathrm{LiCl}(\mathrm{LiCl}$ solubility in acetone $=4.1 \mathrm{~g} / 100 \mathrm{ml})$, acetone is considered as the best solvent for nacrite intercalation. After 3 days of mechanical shaking under a magnetic stirrer, the final hybrid product was obtained and labeled: nacrite-LiCl.

The extent of intercalation was determined using integrated areas of the reflections [28]:

$$
\text { Intercalation Ratio }=\left[\frac{I_{002 h y b r i d}}{I_{002 \text { hybrid }}+I_{002 \text { nacrite }}}\right] \times 100 \%
$$

where $I_{002}$ hybrid and $I_{002}$ nacrite represent the main basal peak intensity of the hydrid and of the unexpanded nacrite component (d 7.2 $\AA$ ), respectively. The intercalation ratio value is equal to $86 \%$ for nacrite- $\mathrm{LiCl}$ and remained unchanged even for long time reaction (Table 1).

\subsection{Characterization Methods}

The intercalation process is characterized via X-ray diffraction analysis, thermogravimetric analysis and IR spectroscopy.

\subsubsection{X-Ray Measurements}

The XRD patterns were obtained at room temperature with the reflection setting on a Bruker D8 installation monitored by the EVA-version Diffrac plus software (Bruker AXS GmbH, Karlsruhe, Germany) and using $\mathrm{CuK} \alpha_{1}$ radiation. Usual scanning parameters were $0.02^{\circ} 2 \theta$ as step size and $6 \mathrm{~s}$ as counting time per step over the angular range $3^{\circ}-55^{\circ} 2 \theta$.

The qualitative XRD investigation consisted in: 1) a global description based on the profile geometry (peak symmetry and/or asymmetry, $d_{00 l}$ basal spacing values, etc.) in order to acquire a preliminary idea of the analyzed sample; 2) the EVA release software, used to identify supplementary reflection due to some persisting impurity attributed to the excess of salt in the surface of the oriented preparations; 3) for all samples, the FWHM and $\bar{M}$ calculations were performed. $\bar{M}$ represents the mean number of layers per stacking deduced from the classic Debye-Scherrer formula:

$$
\bar{M}=\frac{0.886 \lambda}{l d_{001} \cdot F W H M\left({ }^{\circ} 2 \theta\right) \cdot \cos \theta_{00 l}}
$$

where $\lambda$ is the wavelength used, FWHM $\left({ }^{\circ} 2 \theta\right)$ represents the angular width at half-height of 001 XRD reflection and $\left(l d_{001}\right)$ the apparent distance deduced from the maximum intensity for all measurable reflections over the $5^{\circ}-55^{\circ} 2 \theta$ angular range; 4 ) in order to determine the homogeneity and/or heterogeneity of the studied samples, a regularity criterion, using the coefficient of variation, CV, was calculated. This coefficient was introduced by Bailey [29]:

Table 1. The intercalation ratio of nacrite- $\mathrm{LiCl}$ hybrid as a function of time.

\begin{tabular}{rrrr}
\hline Time reaction & $24 \mathrm{~h}$ & $72 \mathrm{~h}$ & $168 \mathrm{~h}$ \\
\hline Intercalation ratio & $86 \%$ & $86 \%$ & $86 \%$ \\
\hline
\end{tabular}




$$
\mathrm{CV}=\frac{100}{d_{m}}\left[\frac{\sum\left(d_{n}-d_{m}\right)^{2}}{n-1}\right]^{1 / 2}
$$

where $d_{n}, d_{m}$ and $n$ represent the apparent spacing deduced from the maximum intensity for all measurable reflections $\left(l d_{00 l}\right)$, the mean basal distance and the number of $00 \mathrm{l}$ reflections respectively. For a regular system, the CV coefficient is less than 0.75 indicating a homogenous complex.

The quantitative XRD analysis has been described by Drits and Tchoubar [30], Ben Rhaiem et al. [31] and is based essentially on the comparison between experimental and theoretical XRD data of the clay mineral. This step is used in order to determine structural parameters related to:

(a) The proportions of the different layer types $\left(W_{i}\right)$;

(b) The stacking mode of the different layer types and the mean number of layers per Coherent Scattering Domain (CSD) [31];

(c) The conditional probability of passing from a layer $i$ to layer $j\left(P_{i j}\right)$.

The relationship between the different kinds of layer proportions and probabilities are given by Drits and Tchoubar [30]:

$$
W_{i}+W_{j}=1, P_{i i}+P_{i j}=1, P_{j i}+P_{j j}=1, W_{i} P_{i j}=W_{j} P_{j i} .
$$

In the case of interstratified phyllosilicate, we distinguish three tendencies:

(a) The segregation tendency is given by: $W_{i}<P_{i i}$ and $W_{j}<P_{i j}$.

(b) The total demixion is obtained for $P_{i i}=P_{j j}=1$.

(c) The regular tendency is obtained if: $W_{i}<P_{j i}<1$ and $W_{j}<P_{i j}<1$; and finally, the limit between the last distribution labeled as a chaotic or random distribution is given when $W_{i}=P_{j i}=P_{i i}$ and $W_{j}=P_{i j}=P_{j j}$; with $\sum W_{i}=1, \sum P_{i j}=1$. The overall fit quality was assessed using the unweighted $\mathrm{R}_{p}$ parameter [32]:

$$
\mathrm{R}_{p}=\sqrt{\frac{\sum\left[I\left(2 \theta_{i}\right) o b s-I\left(2 \theta_{i}\right) \text { calc }\right]^{2}}{\sum\left[I\left(2 \theta_{i}\right) o b s\right]^{2}}}
$$

where, $I_{o b s}$ and $I_{\text {calc }}$ represent measured and calculated intensities, respectively, at the $2 \theta_{i}$ position, the subscript $\boldsymbol{i}$ running over all points in the refined angular range. $\mathrm{R}_{p}$ is mainly influenced by the most intense diffraction maxima, such as the 001 reflections, which contains essential information on the proportions of the different layer types and layer thickness.

The $\mathrm{R}_{p}$ factors, defined as the criteria for representing the agreement between the observed and calculated patterns, are the indication of the best fit when they reach minimum values. In this respect, one has to ensure that the experimental data is reliably accurate and the model chosen must reflect the actual structure as closely as possible [33].

The diffracted intensity was calculated according to the matrix formalism developed by Plançon [34].

$$
I_{00}(2 \theta)=L_{p} \operatorname{Supr}\left(\operatorname{Re}[\Phi][W]\left\{[I]+2 \sum_{n=1}^{M-1}\left[\frac{M-n}{M}\right][Q]^{n}\right\}\right)
$$

where Re indicates the real part of the final matrix; Supr, the sum of the diagonal terms of the real matrix; $L_{p}$, the Lorentz-polarization factor; $M$, the number of layers per stack; $n$, an integer varying between 1 and $M-1$; $[\Phi]$, the structure factor matrix; $[I]$, the unit matrix; $[W]$, the diagonal matrix of the proportions of the different kinds of layers and; $[Q]$, the matrix representing the interference between adjacent layers; $\theta$, the Bragg angle.

\subsubsection{Thermal Analysis}

The thermogravimetric analysis of the nacrite- $\mathrm{LiCl}$ hybrid was carried out using the 92 SETARAM equipment in flowing air, in a temperature ranging from room temperature to $800^{\circ} \mathrm{C}$ along with a heating rate of $5^{\circ} \mathrm{C} / \mathrm{min}$. This technique is very important to monitor the structural modification of kaolinite intercalation hybrids when heated at different temperatures. Although much studies has been accomplished in the areas of kaolinite intercalation reactions, a great deal of work is still required: 1) to make an in depth study of the structure of the formed 
complexes; 2) to understand the parameters responsible for the reactivity; 3) to investigate an effective technique for characterization that can make the intercalation reaction process more clear; and 4) to conduct a detailed study on the phase transition of the intercalation complexes when the temperature of the system is raised [35].

\subsubsection{IR Spectroscopy}

The IR spectra were recorded at room temperature using a thermo scientific Nicolet IR 200 FT-IR with ATR Spectrometer, equipped with a diamond crystal and operating in the medium IR [4000 - $400 \mathrm{~cm}^{-1}$ ] frequency range. IR spectroscopy is established as a reliable tool for the characterization of intercalation hybrids in order to examine the interactions between functional surface groups of the nacrite layers and the alkali halide.

\section{Results and Discussion}

The intercalation process is characterized via X-ray diffraction analysis, thermogravimetric analysis and IR spectroscopy. In the following sections, the structural properties of nacrite-LiCl hybrid will be detailed starting with X-ray diffraction analysis.

\subsection{X-Ray Diffraction}

The analysis of the basal reflections helps determine the structural parameters of the oriented hybrid clay aggregate.

\subsubsection{Qualitative XRD Analysis}

The intercalation process of nacrite, adopted to obtain a stable hydrate has been previously detailed by Ben Haj Amara [23]. The XRD patterns related to the host materials, i.e. natural nacrite, nacrite-KAc and the hydrate are shown in Figures 1(a)-(c), respectively. The shift of the main reflection value from 7.2 to $8.4 \AA$ indicates the presence of a stable hydrate in great accordance with the literature data [19] [23] [25]. The obtained hydrate is then considered as a host matrix to synthesize nacrite-LiCl hybrid material.

Examining the experimental $00 \mathrm{l}$ reflections of the stable nacrite-LiCl hybrid, Figure 2, a main $00 \mathrm{l}$ reflection situated at $2 \theta_{002}=7.724$, with $d_{002}=11.43 \pm 0.02 \AA$ basal spacing value can be seen. This increase is accompanied by the expansion of the interlayer space of nacrite by $\sim 4.23 \AA$ along the $c^{*}$ axis. This result is probably due to the insertion of lithium chloride salt with one water sheet into the nacrite matrix.

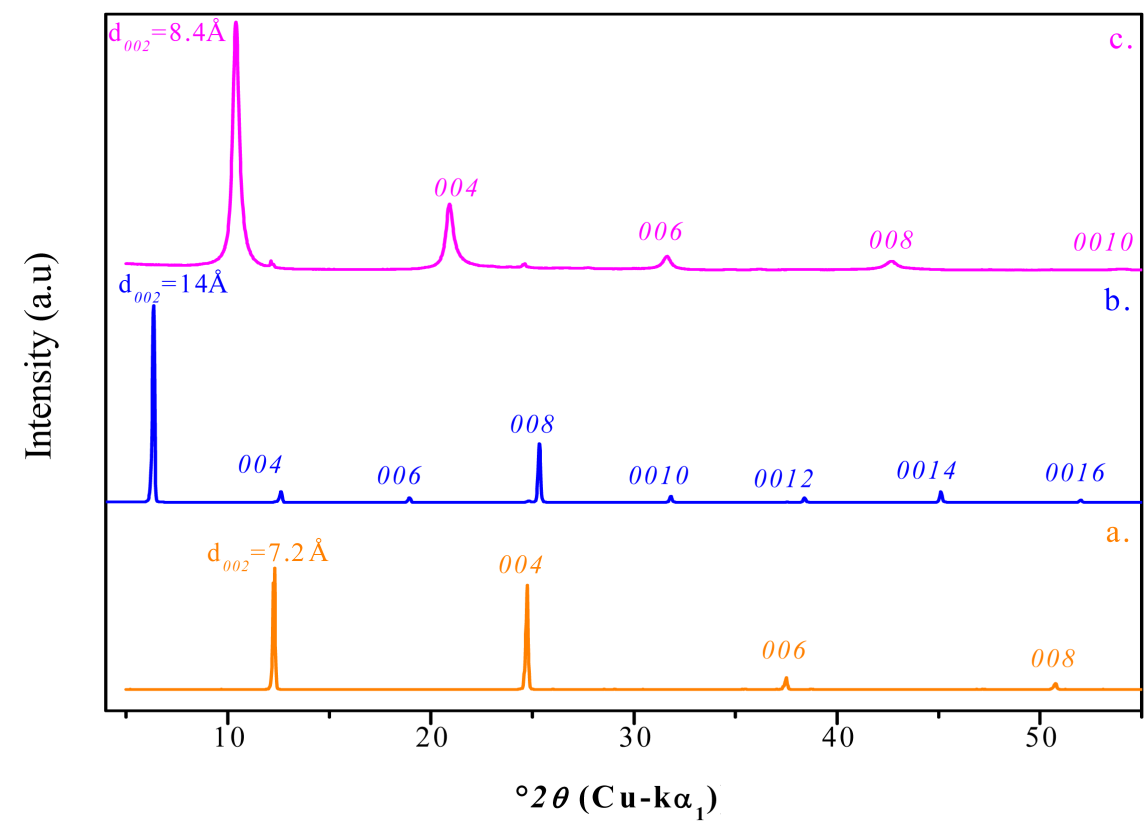

Figure 1. Experimental XRD patterns of natural nacrite (a); nacrite-AcK (b); and hydrate (c). 


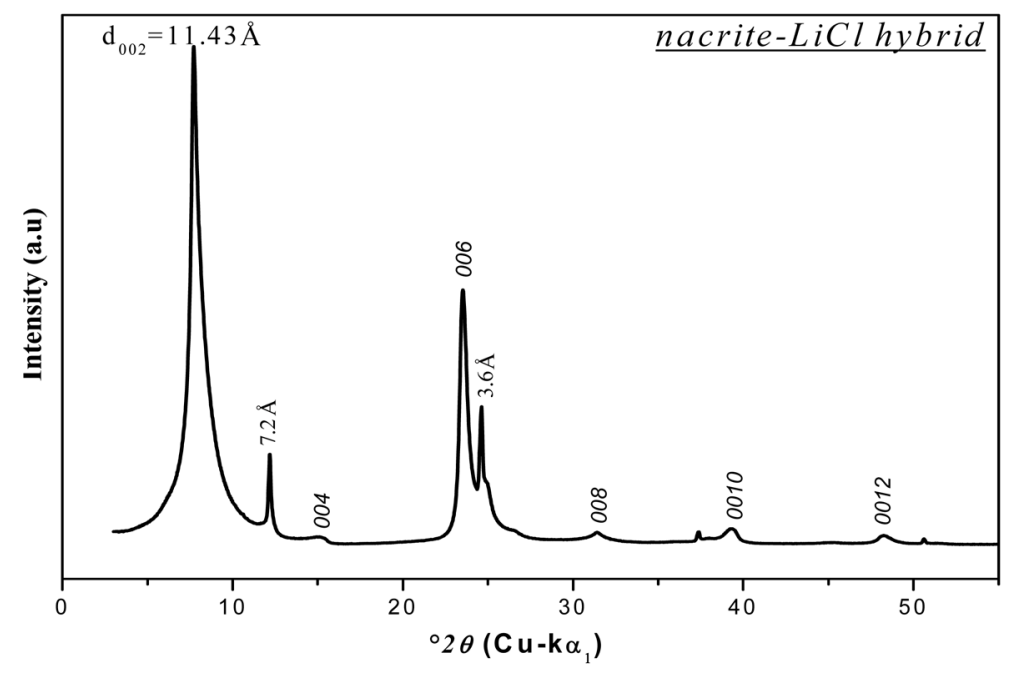

Figure 2. Experimental XRD pattern of the nacrite-LiCl hybrid.

Table 2 shows that the mean number of layers, $\bar{M}$, per crystallite deduced from the Debye-Scherrer formula (Equation (2)) decreases from “ $\bar{M}=70 \pm 1$ ” of natural nacrite [19] to " $\bar{M}=11 \pm 1$ ” of nacrite-LiCl hybrid. This result can be interpreted as "particle" cleavage and as a break of coherence during the intercalation process. The study of the $\boldsymbol{C V}$ coefficient calculated from (Equation (3)) and the rationality of the basal reflections from Table 2 suggest a homogenous sample character. However, the high $F W H M$ value at around $0.846^{\circ} \theta$ of the first reflection (Table 2) is interpreted as a contradictory result. This is underlined by the fact that the $\boldsymbol{F W H M}$ could be significantly affected by stress, strain and interstratifications.

The quantitative study will now be considered because it is much more convincing than the qualitative one.

\subsubsection{Quantitative XRD Analysis}

Simulations of the $00 \mathrm{l}$ seems to be a dominant path to gain an accurate picture about the fine structure of the nacrite-LiCl hybrid and to determine the number and $z$ coordinates of the intercalated species in the interlamellar space of nacrite.

For that, an XRD-modeling computer program designed to carry out intensity calculations was used: Thetheoretical XRD pattern related to the nacrite-LiCl specimen was reproduced to fit the experimental one. However, the small atomic X-ray diffusion factor of $\mathrm{Li}^{+}(2)$ prevents the location of this cation with good accuracy in the interlamellar space of nacrite. So, we dressed a series of models divided on six groups from $A$ to $F$ were we proposed various probabilities of localization of $\mathrm{Li}^{+}$cation (Scheme 1). It was therefore interesting to deal with the $\mathrm{R}_{p}$ factor of each model as an indication of the effectiveness of fit.

From these simulations we concluded that the best model belongs to Group A (Scheme 1) with the smallest $\mathrm{R}_{p}$ factor (6.20\%). Furthermore, we observe a satisfactory agreement between the experimental and theoretical XRD patterns according to both the intensity and the profile (Figure 3). This model allows then a more precise location of $\mathrm{Li}^{+}$cation between the layers of nacrite.

Finally, we deduce the structural parameters of the stable nacrite-LiCl hybrid per half unit-cell:

- One $\mathrm{Li}^{+}$cation placed at $z=9.6 \pm 0.1 \AA$.

- One $\mathrm{Cl}^{-}$anion located at $z=6.4 \pm 0.1 \AA$.

- One water molecule situated at $z=7.9 \pm 0.1$ A sandwiched between the cation and anion.

$z$ coordinates are taken from the oxygen surface oxygen along the normal to the layer.

This model suggests the presence of a hydrated salt and is in concordance with the qualitative analysis.

To sum up, the intercalated species stand vertically in the interlamellar space of nacrite, where the cations are located close to the ditrigonal holes of the tetrahedral layers and the anions are located close to the inner-surface hydroxyls of the octahedral layer of the subsequent sheet.

Moreover, the quantitative study of the nacrite- $\mathrm{LiCl}$ hybrid clearly showed an interstratified stacking characterized by a segregation tendency consisting of a total demixion of two types of layers: Layer A related to a minor fraction (14\%) of the unexpanded $7.2 \AA$ clay and Layer B attributed to a major fraction (86\%) of the interca- 


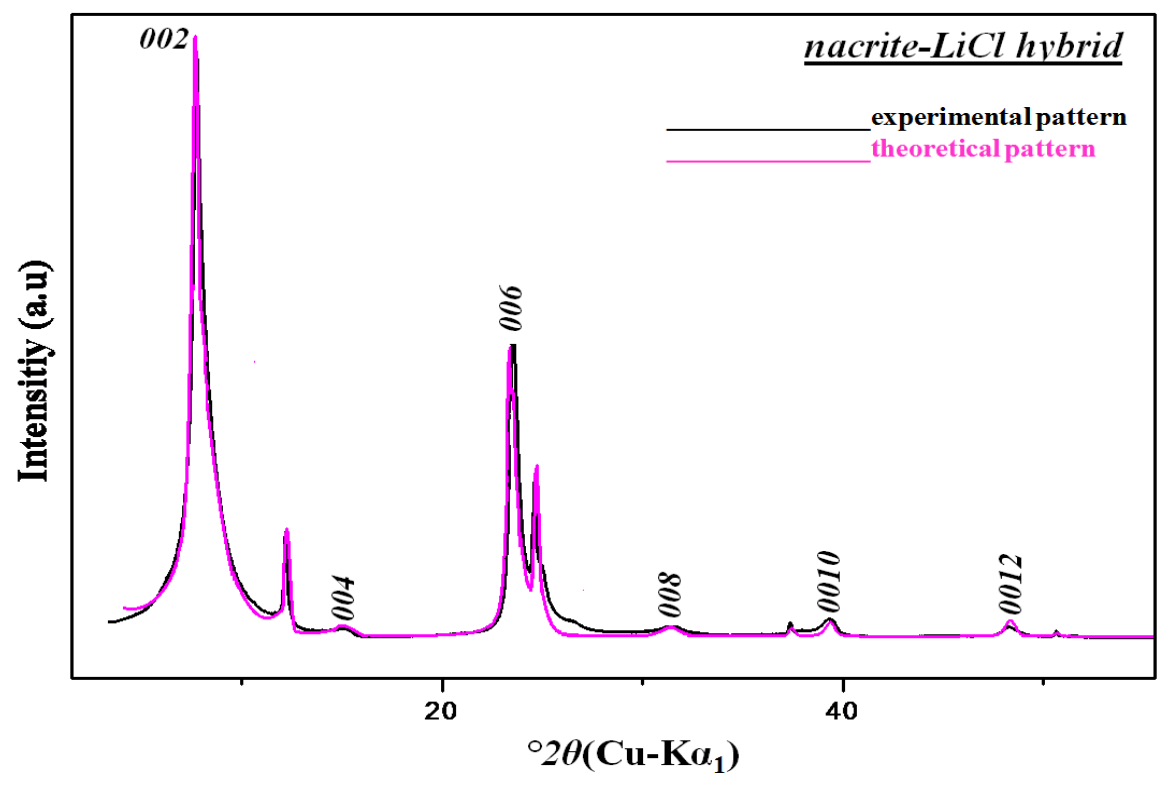

Figure 3. Best agreement between experimental $(-)$ and theoretical $(-)$ XRD patterns of: nacrite-LiCl hybrid.

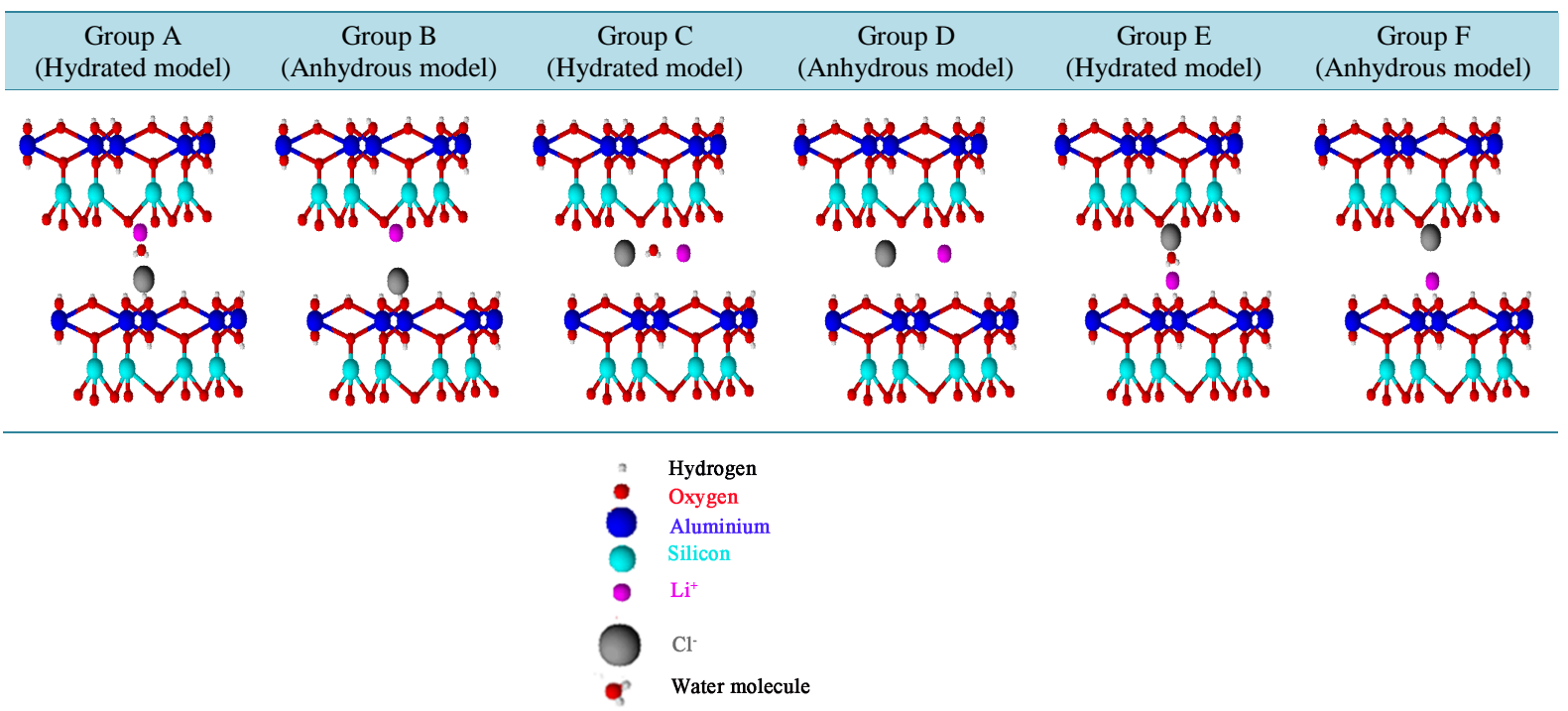

Scheme 1. Representative snapshots of six group of models for XRD fitting of nacrite-LiCl hybrid. Group A: $\left\{\right.$ the $\mathrm{Li}^{+}$cation is located near the oxygen atom plane of the tetrahedral sheet while the $\mathrm{Cl}^{-}$anion is situated near the hydroxyl groups of the octahedral sheet of the adjacent layer and the water molecule is placed between the alkali cation and halide anion\}: The values of $\mathrm{R}_{p}$ factors varied from $6.20 \rightarrow 6.95$. Group $\mathrm{B}$ : \{the $\mathrm{Li}^{+}$cation is located near the oxygen atom plane of the tetrahedral sheet while the $\mathrm{Cl}^{-}$anion is situated near the hydroxyl groups of the octahedral sheet of the adjacent layer $\}$: The values of $\mathrm{R}_{p}$ factors varied from 38.40 $\rightarrow$ 40.90. Group C: $\left\{\right.$ the $\mathrm{Li}^{+}$cation, the $\mathrm{Cl}^{-}$anion and the water molecule stand horizontally in the same line in the middle of the interlamellar space $\}$ : The values of $\mathrm{R}_{p}$ factors varied from $35.32 \rightarrow 39.14$. Group $\mathrm{D}:$ \{the $\mathrm{Li}^{+}$ cation, the $\mathrm{Cl}^{-}$anion stand horizontally in the same line in the middle of the interlamellar space $\}$: The values of $\mathrm{R}_{p}$ factors varied from $39.43 \rightarrow$ 39.63. Group E: $\left\{\right.$ the $\mathrm{Li}^{+}$cation point towards the hydroxyl groups of the octahedral sheet while the $\mathrm{Cl}^{-}$ anion point towards the oxygen atom plane of the tetrahedral sheet of the adjacent layer and the water molecule is placed

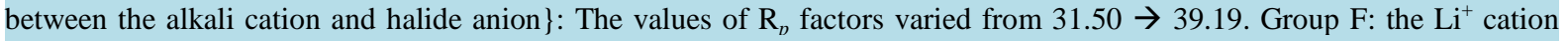
point towards the hydroxyl groups of the octahedral sheet while the $\mathrm{Cl}^{-}$anion point towards the oxygen atom plane of the tetrahedral sheet of the adjacent layer $\}$ : The values of $\mathrm{R}_{p}$ factors varied from $37.00 \rightarrow 39$.62. From these simulations we concluded that the best model belongs to Group A (Scheme 1 ) with the smallest $\mathrm{R}_{p}$ factor $(6.20 \%)$. Furthermore, we observe a satisfactory agreement between the experimental and theoretical XRD patterns according to both the intensity and the profile (Figure 3). This model allows then a more precise location of $\mathrm{Li}^{+}$cation between the layers of nacrite. 
Table 2. Principal results of qualitative analysis of the experimental XRD pattern produced by nacrite-LiCl hybrid.

\begin{tabular}{ccccccc}
\hline $00 l$ Reflections & 002 & 004 & 006 & 008 & 0010 & 0012 \\
\hline$I_{002} / I_{001}$ & 1 & 56.29 & 2.58 & 45.11 & 29.60 & 48.50 \\
$\left(l * \mathrm{~d}_{001}\right)$ app & 11.43 & 11.48 & 11.31 & 11.30 & 11.45 & 11.20 \\
FWHM $(2 \theta)$ & 0.846 & 0.743 & 0.425 & 0.720 & 0.820 & 0.660 \\
M & 9 & 10 & 18 & 10 & 9 & 11 \\
CV & & & $0.71<0.75$ & & & \\
\hline
\end{tabular}

lated nacrite $\left\{W_{A}=0.86, W_{B}=0.14, P_{A A}=1, P_{A B}=0, P_{B A}=0, P_{B B}=1\right\}$. The average number of layers per stacking within each crystallite was around $9 \pm 1$, this value is very close to the experimental $\bar{M}$ value obtained from qualitative analysis. The structural formula of the studied hybrid at room temperature was then determined as; $\left\{(1-\alpha)\left[\mathrm{Si}_{2} \mathrm{Al}_{2} \mathrm{O}_{5}(\mathrm{OH})_{4} \mathrm{LiCl} \cdot \mathrm{H}_{2} \mathrm{O}\right]+\alpha\left[\mathrm{Si}_{2} \mathrm{Al}_{2} \mathrm{O}_{5}(\mathrm{OH})_{4}\right]\right\}$ per half unit cell. Where “ $\alpha$ ” is equal to 0.14 and corresponds to the unexpanded nacrite fraction.

Finally, we remark after comparing our experiment with the previous results of Naamen et al., [17] [36] that the mean basal spacing value of nacrite-LiCl hybrid $\left(d_{002}=11.43 \AA\right)$ is greater than those corresponding to nacrite-KCl hybrid $\left(d_{002}=10.00 \AA\right)$ and nacrite-CsCl hybrid $\left(d_{002}=10.50 \AA\right)$. It is thus concluded that the basal spacing is strongly related to the types of intercalated cation.

\subsection{Thermal Analysis}

Upon thermal treatment, nacrite and/or kaolinite undergo chemical and structural changes. Within the temperature range of $450^{\circ} \mathrm{C}-600^{\circ} \mathrm{C}$, dehydroxylation occurs, the structural $\mathrm{OH}$ are eliminated from the nacrite, the layered structure is destroyed, and nacrite is transformated into metanacrite amorphous phase. The octahedral sheet loses water and decomposes into a disordered meta-state as; $\mathrm{Si}_{2} \mathrm{Al}_{2} \mathrm{O}_{5}(\mathrm{OH})_{4} \rightarrow \mathrm{Si}_{2} \mathrm{Al}_{2} \mathrm{O}_{7}+2 \mathrm{H}_{2} \mathrm{O}$. $\mathrm{Much}$ of the aluminium of the octahedral layer becomes tetrahedrally and pentahedrally coordinated [37].

TG curves (Figure 4) gave evidence that nacrite/LiCl hybrid gradually loses weight from room temperature to $800^{\circ} \mathrm{C}$.

1) The first remarkable weight loss was observed between $25^{\circ} \mathrm{C}-150^{\circ} \mathrm{C}$ and is mostly attributed to the drying process by which the water molecules that are confined to the clay mineral pores are released.

2) The second weight loss $(3.62 \%)$ occurred between $400^{\circ} \mathrm{C}-500^{\circ} \mathrm{C}$ and belongs to the removal of the intercalated water molecule.

This temperature range is also characterized by the beginning of the dehydroxylation of the hybrid at around $450^{\circ} \mathrm{C}$. The chemical decomposition reaction of the hybrid per half unit cell can be expressed as follows:

$$
\begin{aligned}
& \left\{(1-\alpha)\left[\mathrm{Si}_{2} \mathrm{Al}_{2} \mathrm{O}_{5}(\mathrm{OH})_{4} \cdot \mathrm{LiCl}\right]+\alpha\left[\mathrm{Si}_{2} \mathrm{Al}_{2} \mathrm{O}_{5}(\mathrm{OH})_{4}\right]\right\} \\
& \rightarrow\left\{(1-\alpha)\left[\mathrm{Si}_{2} \mathrm{Al}_{2} \mathrm{O}_{7} \cdot \mathrm{LiCl}\right]+\alpha\left[\mathrm{Si}_{2} \mathrm{Al}_{2} \mathrm{O}_{7}\right]\right\}+\left\{2(1-\alpha) \mathrm{H}_{2} \mathrm{O}+2 \alpha \mathrm{H}_{2} \mathrm{O}\right\}
\end{aligned}
$$

The product formed at the beginning of the dehydroxylation of the hybrid is called metahybrid $\mathrm{Si}_{2} \mathrm{Al}_{2} \mathrm{O}_{7} \cdot(1-\alpha) \mathrm{LiCl}$ and is amorphous.

3) The third weight loss was centered around $600^{\circ} \mathrm{C} \mathrm{(9.23 \% )}$ and was due to the removal of two structural waters $\left\{2(1-\alpha) \mathrm{H}_{2} \mathrm{O}+2 \alpha \mathrm{H}_{2} \mathrm{O}\right\}=\left\{2 \mathrm{H}_{2} \mathrm{O}\right\}$ during the calcination process. This step was eventually accompanied by the evolution of the hydrogen halide which results from the following thermal hydrolysis [38] [39]:

$$
2 \mathrm{SiO}_{2} \cdot \mathrm{Al}_{2} \mathrm{O}_{3}+(1-\alpha) \mathrm{LiCl} \rightarrow 2 \mathrm{SiO}_{2} \cdot \mathrm{Al}_{2} \mathrm{O}_{3} \cdot \frac{(1-\alpha)}{2} \mathrm{Li}_{2} \mathrm{O}+(1-\alpha) \mathrm{HCl}-\frac{(1-\alpha)}{2} \mathrm{H}_{2} \mathrm{O}
$$

On the clay surface a liberated water molecule associates with $\mathrm{Cl}^{-}$to form volatile $\mathrm{HCl}$. The volatilization of $\mathrm{HCl}$ is responsible for a great amount of thermal mass loss of the examined hybrid. This phenomenon causes the trapping of the alkali metal oxide $\mathrm{Li}_{2} \mathrm{O}$ within the metanacrite matrix. The amorphous metahybrid phase formed during this step have the following chemical formula: $\left\{\mathrm{Si}_{2} \mathrm{Al}_{2} \mathrm{O}_{7} \cdot \frac{(1-\alpha)}{2} \mathrm{Li}_{2} \mathrm{O}\right\}$. Knowing that $\frac{(1-\alpha)}{2}$ coefficient is equal to $0.43 \sim 0.5$, we can simplify this chemical formula and express our metahybrid by the following formula $\left\{\mathrm{Si}_{2} \mathrm{Al}_{2} \mathrm{O}_{7} \cdot \frac{1}{2} \mathrm{Li}_{2} \mathrm{O}\right\}$. 


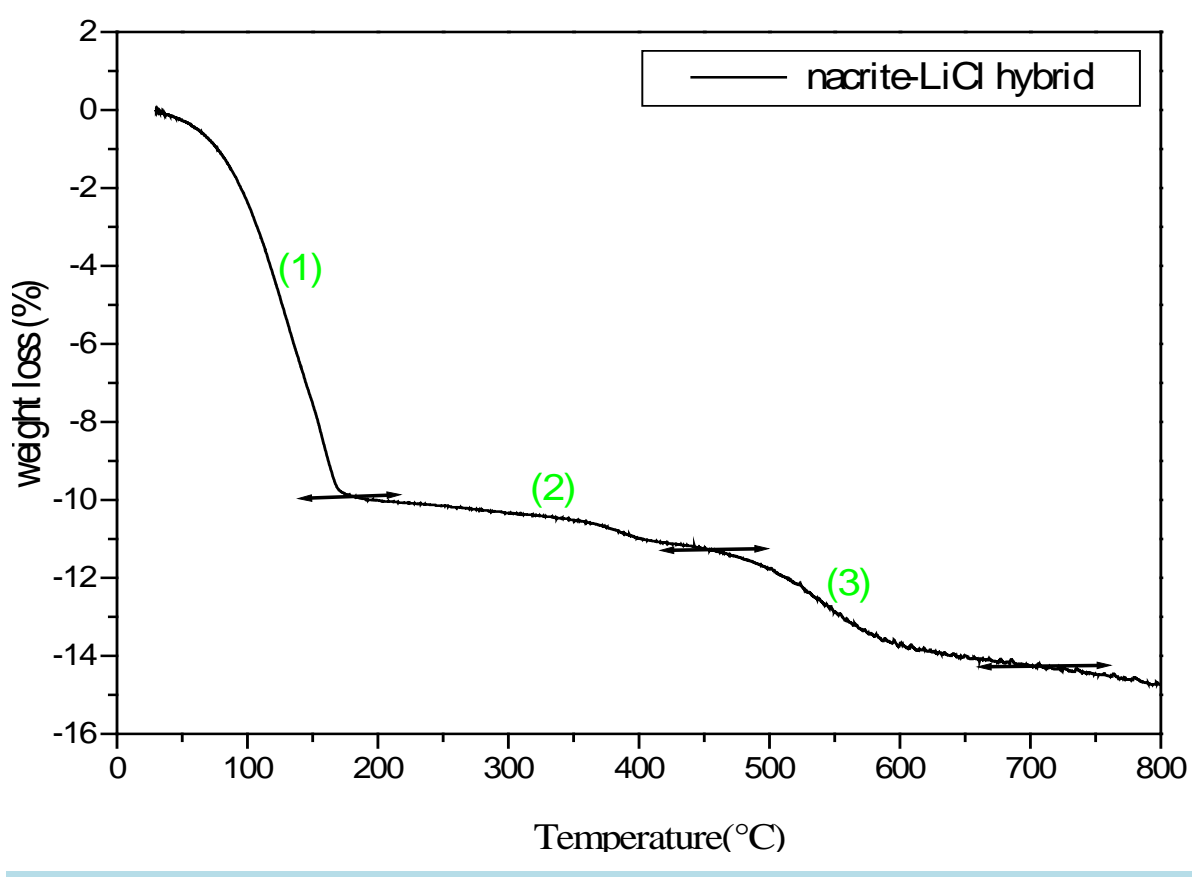

Figure 4. TG curve of the nacrite- $\mathrm{LiCl}$ hybrid heated from room temperature to $800^{\circ} \mathrm{C}$.

It is therefore deduced that the thermal decomposition processes of the nacrite-LiCl hybrid takes place in three steps that enable us to estimate the content of the clay hybrid (Table 3). The presence of one water molecule in the interlamellar space of nacrite was noticed, which confirms the quantitative XRD analysis. Moreover, the thermogravimetric curves revealed that the dehydroxylation of nacrite-intercalate was slightly altered from that of the unmodified nacrite [23].

\subsection{IR Spectroscopy}

By comparing the spectrum of nacrite intercalated with lithium chloride to the spectrum of the untreated nacrite, it is possible to follow the modification of the stretching and deformation vibrations: they shift from their positions in the spectrum of untreated nacrite, and their shapes change. These effects are a consequence of several factors, such as the cation, the anion and the degree of intercalation and hydration [8].

These modifications are manifested in the recorded spectrum of the nacrite-LiCl hybrid by (Figure 5 and Table 4):

a) The disappearance of the $\mathrm{OH}$ lattice stretching band since it is located in the envelope of the strong $\mathrm{HOH}$ band; this may be undetectable in the spectrum.

b) The appearance of $\mathrm{HOH}$ stretching and bending vibrations which do not occur in the spectrum of natural nacrite.

c) Shifts of $\mathrm{Al}-\mathrm{OH}$ deformation vibrations to lower frequencies and shifts of Al-O deformation vibrations to higher frequencies.

d) Shifts of the Si-O stretching and deformation vibrations.

The weakening of the Al-OH stretching vibrations as well as the shifts of the Al-OH deformation vibrations, indicate that the inner surface hydroxyls of the octahedral layer form hydrogen bonds with the $\mathrm{Cl}^{-}$ions $(\mathrm{O}-\mathrm{H}$... Cl $)$. It is important to note that the hydrogen bonds between the chlorides and the inner surface $\mathrm{OH}$ groups are much stronger than those between the chlorides and the inner OH groups [8].

A concomitant appearance of a new, symmetric and strong water band at $3456 \mathrm{~cm}^{-1}$ is an indication that the intercalated $\mathrm{H}_{2} \mathrm{O}$ molecule is bonded to both ions of the salt, the alkali and the halogen [20] [40]. The cation is bound to the $\mathrm{H}_{2} \mathrm{O}$ oxygen by an ion-dipole electrostatic interaction whereas the anion is bound through a hydrogen bond in which the water molecule acts as a proton donor as follows: Li...O(H)-H...Cl [20] [40].

It should be mentioned that shifts of the Si-O stretching and deformation vibrations in the infrared spectrum of the studied hybrid indicate that these bonds are weak. This is due to the strength of the bonds formed between 


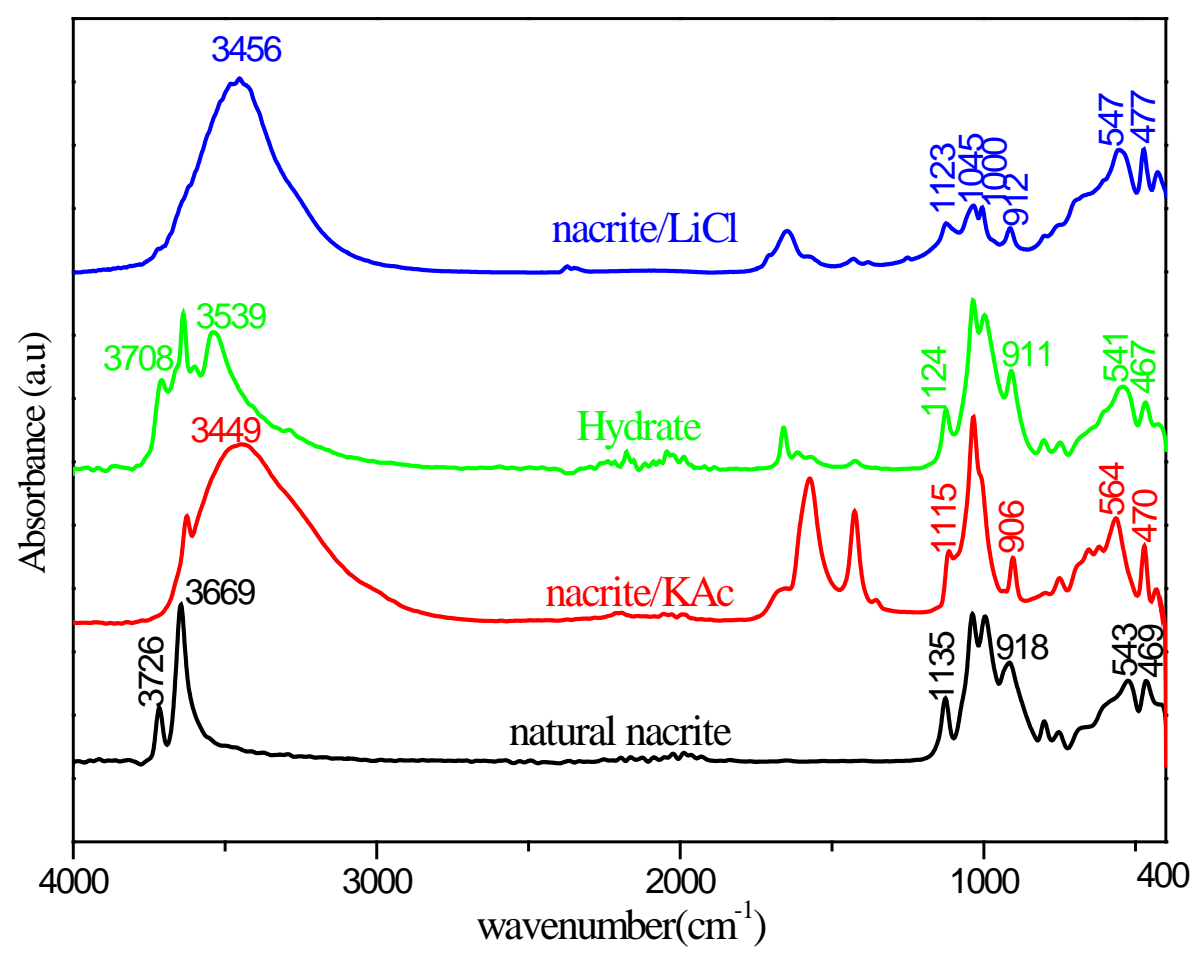

Figure 5. Infrared spectra of natural nacrite, nacrite-KAc, hydrate and nacrite-LiCl hybrid.

Table 3. Weight losses of the elaborated nacrite-LiCl hybrid.

\begin{tabular}{ccc}
\hline Nacrite-LiCl Hybrid & $\frac{\Delta m}{m}$ & $-n \mathrm{H}_{2} \mathrm{O}$ \\
Weight Loss 1 & $30.82 \%$ & $-7 \mathrm{H}_{2} \mathrm{O}$ \\
Weight Loss 2 & $3.62 \%$ & $-1 \mathrm{H}_{2} \mathrm{O}$ \\
Weight Loss 3 & $9.23 \%$ & $-2 \mathrm{H}_{2} \mathrm{O}$ \\
Total Weight Loss & $43.68 \%$ & \\
\hline
\end{tabular}

Table 4. Frequencies and assignments of IR absorption bands in the $4000-400 \mathrm{~cm}^{-1}$ region for natural nacrite, nacrite-KAc, the hydrate and nacrite-LiCl hybrid.

\begin{tabular}{|c|c|c|c|c|}
\hline \multirow{2}{*}{ Band assignment } & \multicolumn{4}{|c|}{ Samples } \\
\hline & Natural nacrite & Nacrite-KAc & Nacrite- $\mathrm{H}_{2} \mathrm{O}$ & Nacrite-LiCl \\
\hline AlO-H stretching & $\begin{array}{l}3726 \\
3669\end{array}$ & $\begin{array}{c}- \\
3635\end{array}$ & $\begin{array}{l}3708 \\
3637\end{array}$ & \\
\hline Intercalated HOH symmetrical stretching & - & 3449 & 3539 & 3456 \\
\hline Intercalated $\mathrm{HOH}$ bending & - & 1662 & 1659 & 1658 \\
\hline Si-O stretching & $\begin{array}{l}1135 \\
1045 \\
1008\end{array}$ & $\begin{array}{l}1115 \\
1034 \\
1011\end{array}$ & $\begin{array}{c}1124 \\
1034 \\
997\end{array}$ & $\begin{array}{l}1123 \\
1045 \\
1000\end{array}$ \\
\hline Al-OH deformation & $\begin{array}{l}918 \\
807 \\
757\end{array}$ & $\begin{array}{c}906 \\
- \\
751\end{array}$ & $\begin{array}{l}911 \\
801 \\
745\end{array}$ & $\begin{array}{l}912 \\
788 \\
738\end{array}$ \\
\hline Al-O deformation & 543 & 564 & 541 & 547 \\
\hline Si-O deformation & 469 & 470 & 467 & 477 \\
\hline
\end{tabular}


water molecules and $\mathrm{Cl}^{-}$ions. Consequently, the ability of the inserted water molecule to donate its second proton to an oxygen atom of the silicate layer leads to a weak Si-O...H-OH hydrogen bond. This result is in great accordance with the previous studies of Yariv et al., [8] about the keying of chloride salts into the kaolin-type clay minerals.

Finally, IR spectroscopy proved that the penetrating $\mathrm{LiCl}$ species overcome the strong electrostatic and van der Waals interactions between the nacrite-like layers and form hydrogen bonds with components of the TO layer. 1) The $\mathrm{Cl}^{-}$halide anion interacts with the inner surface hydroxyls through hydrogen-bonding; 2) The intercalated water molecule only interacts with the $\mathrm{Cl}^{-}$and $\mathrm{Li}^{+}$ions; 3) The $\mathrm{Li}^{+}$alkali cation, located near the basal oxygens of the nacrite layer, interacts electrostatically with the negatively charged oxygens of the inner-surface oxygen (Figure 6 and Figure 7). This result is in agreement with those suggested by [41] [42].

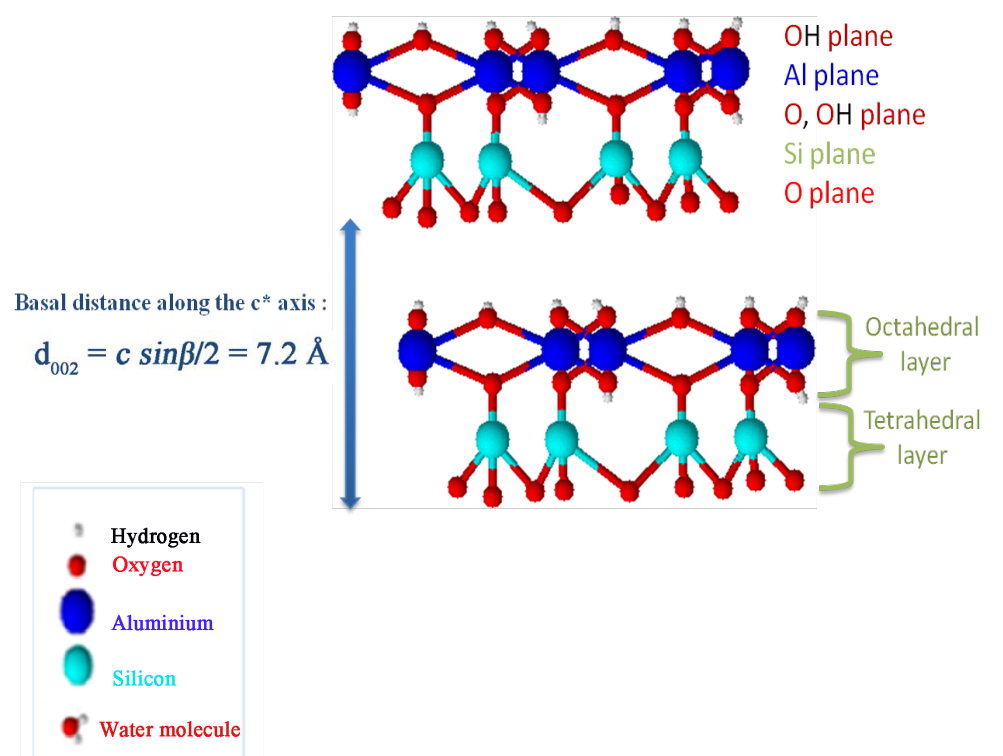

Figure 6. Representative snapshots of natural nacrite.

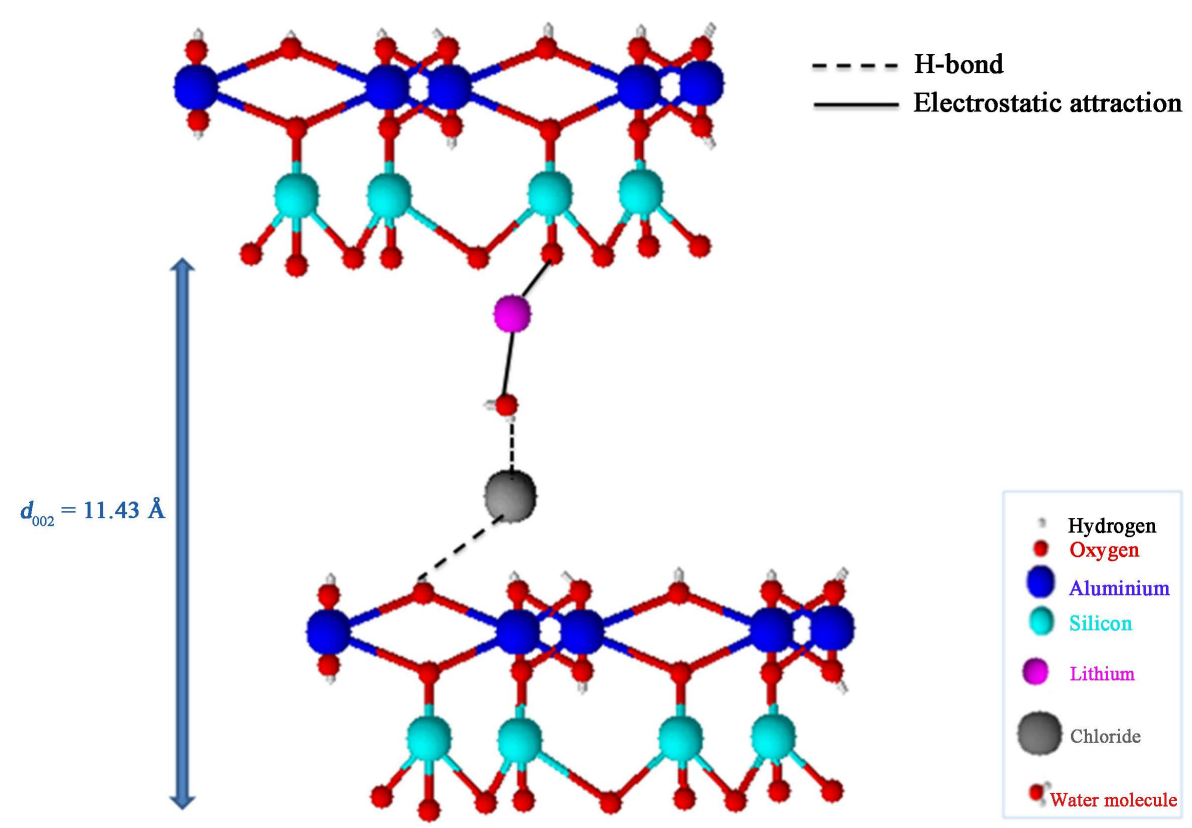

Figure 7. The possible structural model for nacrite- $\mathrm{LiCl}$ hybrid and the bonding between the activegroups on the nacrite layers and the intercalated species. 


\section{Conclusion}

In this work, structural experiments have been conducted in order to characterize the salt intercalation process between the nacrite layers. The stable intercalated material has been characterized by XRD, TG and IR analyses. The XRD pattern showed basal spacing at $11.43 \AA$ with integral series of $00 \mathrm{l}$ reflections indicating an ordered structure of parallel 1:1 layers. The quantitative XRD analysis showed that best agreement between the observed and simulated patterns $\left(\mathrm{R}_{p}=6.20 \%\right)$ was obtained with one $\mathrm{Cl}^{-}$ion at $z=6.4 \pm 0.1 \AA$, one $\mathrm{Li}^{+}$ion at $z=9.6 \pm$ $0.1 \AA$ and one $\mathrm{H}_{2} \mathrm{O}$ at $z=7.9 \pm 0.1 \AA$ in the interlamellar space of nacrite (per half-unit cell). The Li ${ }^{+}$cation was located near the oxygen atom plane while the $\mathrm{Cl}^{-}$anion was near the hydroxyl groups of the adjacent layer. The TG analysis of the hybrid produced showed a loss of water between $450^{\circ} \mathrm{C}-600^{\circ} \mathrm{C}$, the weight loss $(1$ molecule per half unit cell) corresponding to the interlamellar water, in agreement with that showed by XRD. The positions of the $\mathrm{H}_{2} \mathrm{O}$ molecules, $\mathrm{Li}^{+}$and $\mathrm{Cl}^{-}$suggest an interaction between $\mathrm{Li}^{+}$and the basal oxygens on one side and $\mathrm{Cl}^{-}$and the surface hydroxyls on the other side. The $\mathrm{H}_{2} \mathrm{O}$ can establish binding either with $\mathrm{Li}^{+}$cation or $\mathrm{Cl}^{-}$ ions.

\section{Acknowledgements}

N. Jaafar acknowledges Pr. A. Ben Haj AMARA (Laboratory of Physics of Lamellar Hybrid Materials and Nanomaterials: UR05/13-01, Department of Physics, Faculty of Science of Bizerte, Zarzouna 7021, TUNISIA) for the fruitful discussions about clay mineral behavior, his main contribution in the XRD modeling approach and the proof readings of the manuscript. The content and style of the paper greatly benefited from comments of reviewers and those of the editor.

\section{References}

[1] Bergaya, F. and Lagaly, G. (2006) General Introduction: Clays, Clay Minerals, and Clay Science. In: Bergaya, F., Theng, B.K.G. and Lagaly, G., Eds., Handbook of Clay Science: Developments in Clay Science, Vol. 1, Elsevier, Amsterdam, 1-18. http://dx.doi.org/10.1016/S1572-4352(05)01001-9

[2] Silva, F.A.N.G., Luz, A.B., Sampaio, J.A., Bertolino, L.C., Scorzelli, R.B., Duttine, M. and da Silva, F.T. (2009) Technological Characterization of Kaolin: Study of the Case of the Borborema-Seridó Region (Brazil). Applied Clay Science, 44, 189-193. http://dx.doi.org/10.1016/j.clay.2009.01.015

[3] Carretero, M.I. and Pozo, M. (2010) Clay and Non-Clay Minerals in the Pharmaceutical and Cosmetic Industries Part II. Active Ingredients. Applied Clay Science, 47, 171-181. http://dx.doi.org/10.1016/j.clay.2009.10.016

[4] Rondón, W., Freire, D., de Benzo, Z., Sifontes, A.B., González, Y., Valero, M. and Brito, J.L. (2013) Application of 3A Zeolite Prepared from Venezuelan Kaolin for Removal of Pb(II) from Wastewater and Its Determination by Flame Atomic Absorption Spectrometry. American Journal of Analytical Chemistry, 4, 584-594. http://dx.doi.org/10.4236/ajac.2013.410069

[5] Kabwadza-Corner, P., Munthali, M.W., Johan, E. and Matsue, N. (2014) Comparative Study of Copper Adsorptivity and Selectivity toward Zeolites. American Journal of Analytical Chemistry, 5, 395-405. http://dx.doi.org/10.4236/ajac.2014.57048

[6] Castellano, M., Turturro, A., Riani, P., Montanari, T., Finocchio, E., Ramis, G. and Busca, G. (2010) Bulk and Surface Properties of Commercial Kaolins. Applied Clay Science, 48, 446-454. http://dx.doi.org/10.1016/j.clay.2010.02.002

[7] Bailey, S.W. (1963) Polymorphism of the Kaolin Minerals. American Mineralogist, 48, 1197-1209.

[8] Yariv, S., Lapides, I., Michaelian, K.H. and Lahav, N. (1999) Thermal Intercalation of Alkali Halides into Kaolinite. Journal of Thermal Analysis and Calorimetry, 56, 865-884. http://dx.doi.org/10.1023/A:1010187029708

[9] Yariv, S. and Lapides, I. (2000) The Effect of Mechanochemical Treatments on Clay Minerals and the Mechanochemical Adsorption of Organic Materials onto Clay Minerals. Journal of Materials Synthesis and Processing, 8, 223-233.

[10] Komori, Y. and Sugahara, Y. (1998) A Kaolinite-NMF-Methanol Intercalation Compound as a Versatile Intermediate for Further Intercalation Reaction of Kaolinite. Journal of Materials Research, 13, 930-934. http://dx.doi.org/10.1557/JMR.1998.0128

[11] Orzechowski, K., Slonka, T. and Glowinski, J. (2006) Dielectric Properties of Intercalated Kaolinite. Journal of Physics and Chemistry of Solids, 67, 915-919. http://dx.doi.org/10.1016/j.jpcs.2006.03.001

[12] Letaief, S., Diaco, T., Pell, W., Gorelsky, S.I. and Detellier, C. (2008) Ionic Conductivity of Nanostructured Hybrid Materials Designed from Imidazolium Ionic Liquids and Kaolinite. Chemistry of Materials, 20, 7136-7142. http://dx.doi.org/10.1021/cm800758c 
[13] Vagvolgyi, V., Kovacs, J., Horvath, E., Kristof, J. and Mako, E. (2008) Investigation of Mechanochemically Modified Kaolinite Surfaces by Thermoanalytical and Spectroscopic Methods. Journal of Colloid and Interface Science, 317, 523-529. http://dx.doi.org/10.1016/j.jcis.2007.09.085

[14] Michaelian, K.H., Lapides, I., Lahav, N., Yariv, S. and Brodsky, I. (1998) Infrared Study of the Intercalation of Kaolinite by Caesium Bromide and Caesium Iodide. Journal of Colloid and Interface Science, 204, 389-393. http://dx.doi.org/10.1006/jcis.1998.5577

[15] Ben Haj Amara, A., Ben Brahim, J., Besson, G. and Pons, C.H. (1995) Study of Intercalated Nacrite with Dimethylsufoxide and n-Methylacetamide. Clay Minerals, 30, 295-306. http://dx.doi.org/10.1180/claymin.1995.030.4.03

[16] Ben Haj Amara, A., Ben Rhaiem, H. and Plançon, A. (2000) Structural Evolution of Nacrite as a Function of the Nature of the Intercalated Organic Molecules. Journal of Applied Crystallography, 33, 1351-1359. http://dx.doi.org/10.1107/S0021889800011730

[17] Naamen, S., Ben Rhaiem, H. and Ben Haj Amara, A. (2004) XRD Study of the Nacrite/CsCl/ $\mathrm{H}_{2} \mathrm{O}$ Intercalation Complex. Materials Science Forum, 443-444, 59-64.

[18] Jaafar, N., Ben Rhaiem, H. and Ben Haj Amara, A. (2014) Synthesis, Characterization and Applications of a New Nanohybrid Composite: Nacrite/ $\mathrm{MgCl}_{2} \cdot 6 \mathrm{H}_{2} \mathrm{O} /$ Ethanol. International Conference on Composite Materials \& Renewable Energy Applications (ICCMREA), IEEE Xplore Digital Library, Sousse, 22-24 January 2014, 1-6.

[19] Ben Haj Amara, A., Plançon, A., Ben Brahim, J. and Ben Rhaiem, H. (1998) XRD Study of the Stacking Mode in Natural and Hydrated Nacrite. Materials Science Forum, 278-281, 809-813. http://dx.doi.org/10.4028/www.scientific.net/MSF.278-281.809

[20] Michaelian, K.H., Yariv, S. and Nasser, A. (1991) Study of the Interactions between Caesium Bromide and Kaolinite by Photoacoustic and Diffuse Reflectance Infrared Spectroscopy. Canadian Journal of Chemistry, 69, 749-754. http://dx.doi.org/10.1139/v91-110

[21] Lapides, I., Lahav, N., Michaelian, K.H. and Yariv, S. (1997) X-Ray Study of the Thermal Intercalation of Alkali Halides into Kaolinite. Journal of Thermal Analysis, 49, 1423-1432. http://dx.doi.org/10.1007/BF01983701

[22] Cruz, M., Jacobs, H. and Fripiat, J.J. (1973) Interlayer Bonding in Kaolin Minerals. Proceedings of the International Clay Conference, 1972, CSIC, Madrid: Division de Ciencias, Madrid, Spain, 35-46.

[23] Ben Haj Amara, A. (1997) X-Ray Diffraction, Infrared and TGA/DTG Analysis of Hydrated Nacrite. Clay Minerals, 32, 463-470. http://dx.doi.org/10.1180/claymin.1997.032.3.08

[24] Ben Haj Amara, A., Ben Brahim, J., Ben Ayed, N. and Ben Rhaiem, H. (1996) Occurence of Nacrite in Old Pb-Zn Deposits from Northern Tunisia. Clay Minerals, 31, 127-130. http://dx.doi.org/10.1180/claymin.1996.031.1.11

[25] Ben Haj Amara, A., Ben Brahim, J., Plançon, A. and Ben Rhaiem, H. (1998) X-Ray Diffraction Study of the Stacking Modes of Hydrated and Dehydrated Nacrite. Journal of Applied Crystallography, 31, 654-662. http://dx.doi.org/10.1107/S0021889898000363

[26] Weiss, A., Thielepape, W. and Orth, H. (1966) Neue Kaolinit-Einlagerungsverbindungen. In: Rosenquist, T. and GraffPetterson, P., Eds., Proceedings of the International Clay Conference, Israel University Press, Jerusalem, Vol. 1, 277-293.

[27] Garrett, W.G. and Walker, G.F. (1959) The Cation-Exchange Capacity of Hydrated Halloysite and the Formation of Halloysite-Salt Complexes. Clay Minerals, 4, 75-80. http://dx.doi.org/10.1180/claymin.1959.004.22.02

[28] Wiewióra, A. and Brindley, G.W. (1969) Potassium Acetate Intercalation in Kaolinites and Its Removal: Effect of Material Characteristics. Proceedings of the International Clay Conference, L .Heller, Ed., Israel University Press, Jerusalem, Vol. 1, 723-733.

[29] Bailey, S.W. (1982) Nomenclature for Regular Interstratifications. Clay Minerals, 17, 243-248. http://dx.doi.org/10.1180/claymin.1982.017.2.09

[30] Drits, V.A. and Tchoubar, C. (1990) The Modelization Method in the Determination of the Structural Characteristics of Some Layer Silicates: Internal Structure of the Layers, Nature and Distribution of Stacking Faults. In: X-Ray Diffraction by Disordered Lamellar Structures, Springer-Verlag, Berlin, 233-303.

[31] Ben Rhaiem, H., Tessier, D. and Ben Haj Amara, A. (2000) Mineralogy of the $<2 \mu \mathrm{m}$ Fraction of Three Mixed-Layer Clays from Southern and Central Tunisia. Clay Minerals, 35, 375-381. http://dx.doi.org/10.1180/000985500546846

[32] Howard, S.A. and Preston, K.D. (1989) Profile Fitting of Powder Diffraction Patterns. In: Bish, D.L. and Post, J.E., Eds., Modern Powder Diffraction: Reviews in Mineralogy, Mineralogical Society of America, Washington DC, 217275.

[33] Taser, M., Kuçukcelebi, H., Armagan, N. and Güler, C. (1997) Use of R Factors in the Study of the Structural Defects in Phyllosilicates by X-Ray Powder Diffraction. Journal of Applied Crystallography, 30, 55-58. http://dx.doi.org/10.1107/S0021889896008916

[34] Plançon, A. (1981) Diffraction by Layer Containing Different Kinds of Layers and Stacking Faults. Journal of Applied 
Crystallography, 14, 300-304. http://dx.doi.org/10.1107/S0021889881009424

[35] Cheng, H., Liua, Q., Yang, J., Ma, S. and Frost, R.L. (2012) The Thermal Behavior of Kaolinite Intercalation Complexes-A Review. Thermochimica Acta, 545, 1-13. http://dx.doi.org/10.1016/j.tca.2012.04.005

[36] Naamen, S., Ben Rhaiem, H., Karmous, M.S. and Ben Haj Amara, A. (2004) XRD Study of the Stacking Mode of the Nacrite/Alkali Halides Complexes. Materials Structure, 11.

[37] Leluk, K., Orzechowski, K., Jerieb, K., Baranowskib, A., Slonkac, T. and Glowinskic, J. (2010) Dielectric Permittivity of Kaolinite Heated to High Temperatures. Journal of Physics and Chemistry of Solids, 71, 827-831. http://dx.doi.org/10.1016/j.jpcs.2010.02.008

[38] Heller-Kallai, L. (1978) Reactions of Salts with Kaolinite at Elevated Temperatures. Clay Minerals, 13, $221-235$. http://dx.doi.org/10.1180/claymin.1978.013.2.09

[39] Gabor, M., Poeppl, L. and Koeros, E. (1986) Effect of Ambient Atmosphere on Solid State Reaction of Kaolin-Salt Mixtures. Clays and Clay Minerals, 34, 529-533. http://dx.doi.org/10.1346/CCMN.1986.0340505

[40] Frost, R.L., Kristof, J., Mako, E. and Kloprogge, J.T. (2000) Modification of the Hydroxyl Surface in Potassium-AcetateIntercalated Kaolinite between 25 and $300^{\circ}$ C. Langmuir, 16, 7421-7428. http://dx.doi.org/10.1021/la9915318

[41] Yariv, S. (1986) Interactions of Minerals of the Kaolin Group with Cesium Chloride and Deuteration of the Complexes. International Journal of Tropical Agricultural, 5, 310-322.

[42] Michaelian, K.H., Friesen, W.I., Yariv, S. and Nasser, A. (1991) Diffuse Reflectance Infrared Spectra of Kaolinite and Kaolinite/Alkali Halide Mixtures. Curve-Fitting of the OH Stretching Region. Canadian Journal of Chemistry, 69, 1786-1790. http://dx.doi.org/10.1139/v91-262 
Scientific Research Publishing (SCIRP) is one of the largest Open Access journal publishers. It is currently publishing more than 200 open access, online, peer-reviewed journals covering a wide range of academic disciplines. SCIRP serves the worldwide academic communities and contributes to the progress and application of science with its publication.

Other selected journals from SCIRP are listed as below. Submit your manuscript to us via either submit@scirp.org or Online Submission Portal.
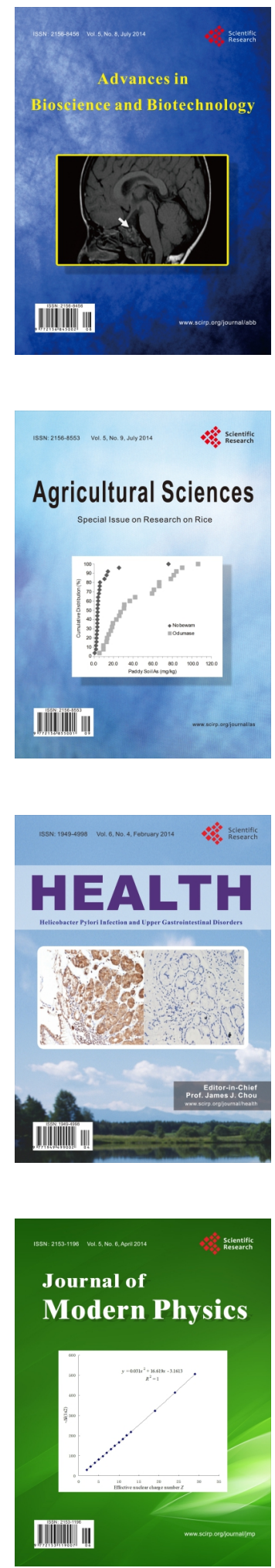
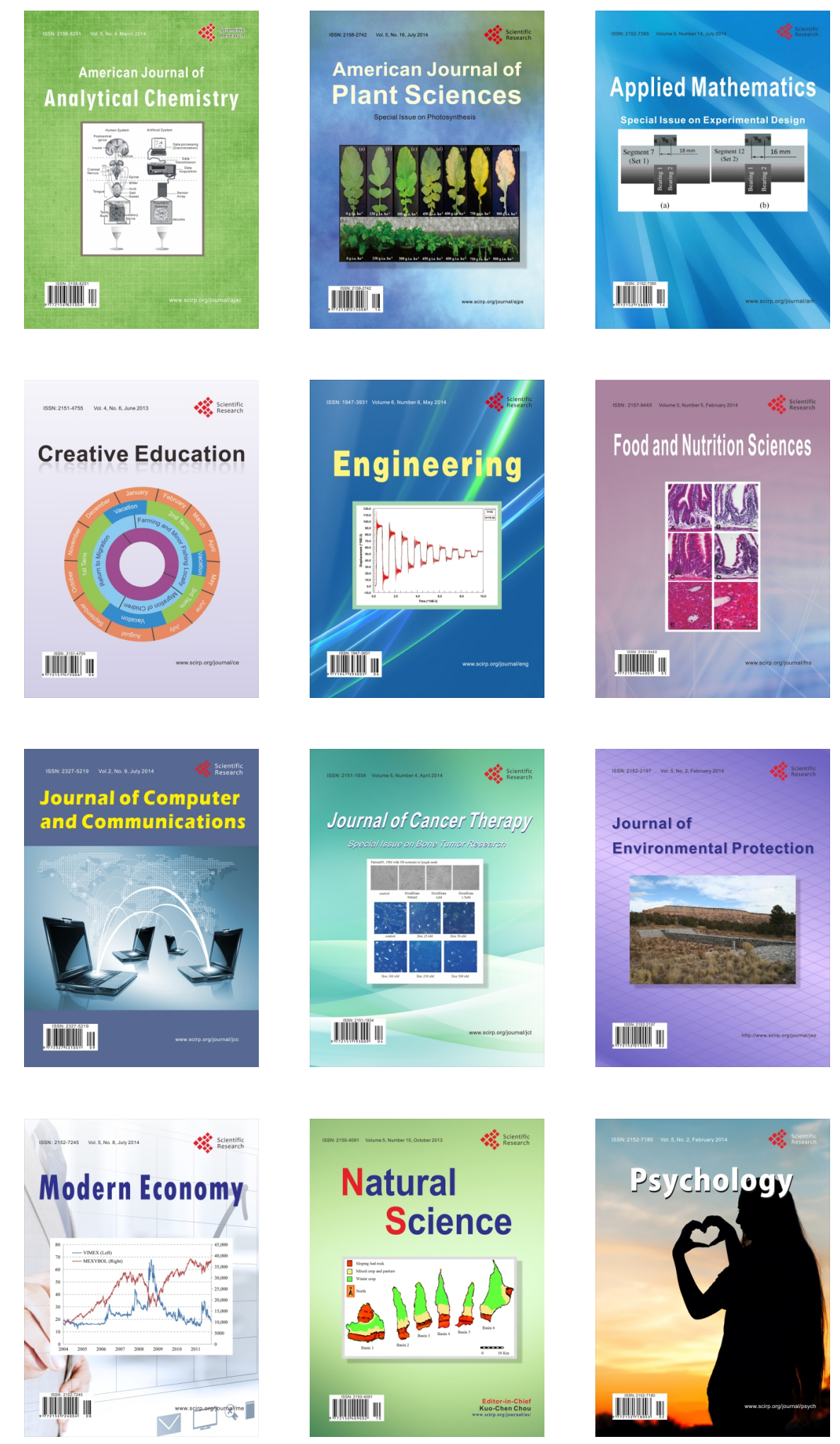